\title{
ФЕНОМЕН АРХЕТИПУ ЯК СПІВ-БУТТЯ У НАУКОВОМУ ДИСКУРСІ МУЗИЧНОЇ КУЛЬТУРОЛОГІЇ
}

\section{Северинова М. Ю.}

\section{ВСТУП}

Сучасна культура характеризується розімкненим, некласичним сприйняттям світу, наростанням мозаїчності, перенасиченням культурних форм. 3 одного боку, художня свідомість XXI століття відчуває безструктурність і невиразність сучасної реальності, неможливість ії пояснити вже наявними поетичними, музичними, філософськими формулами. 3 іншого - залишається нездоланним прагненням художника перетворювати хаос на порядок, спираючись на глобальні уявлення про можливості свого мистецтва. У зв'язку із цим особливо важливим постає пошук первинних, внутрішніх основ, які не тільки продукували б розмаїття історично ускладнених художніх форм, але й були б еквівалентом загальнолюдського, загальнокультурного. Одними із таких основ, найважливішими елементами, універсаліями культури є архетипи.

Доктрина ейдетичного, первообразного розуміння світу, що була закладена у часи Античності, широко використовувалася мислителями, теологами, митцями протягом усієї історії культури людства. Проте свою квінтесенцію вона здобула лише у XX столітті у вченні К. Юнга про колективне позасвідоме, узагальнюючі образи якого були названі архетипами, та у працях його послідовників, котрі продовжували розмірковування щодо буттєвості архетипів як універсалій у сфері фундаментальної онтології, структурної антропології, аналітичної та трансперсональної психології, літературознавстві, музикознавстві тощо. Так, Е. Кассірер у якості універсалії бачить «первообраз» i «праобраз» усього сущого; Є. Мелетинський вводить поняття «архетиповий мотив» і «архетиповий сюжет», дослідники семіотики $\mathrm{XX}$ ст. говорять про культурний код як про поняття, що є тотожним поняттю інваріантної структури, архетипу; М. Еліаде розуміє архетип як божественний зразок, а Космос як ідеальний архетип і т. ін.

Однією з ознак та теоретичних досягнень сучасної культури можна назвати онтологізацію розуміння та визначення статусу феномену «співбуття», який розглядається нами у контексті архетипів. Відтак архетип розглядається як спів-буття (рос. - со-бытие). Зазначимо, що точний 
переклад цього слова українською мовою - подія, але для нас важливим $\epsilon$ адекватний переклад слова як терміна, що містить певне дискурсивне значення, пов'язане із сучасним філософсько-культурологічним мисленням. Тож виникає необхідність розглянути феномен «спів-буття» у контексті його архетиповості i, навпаки, розглянути архетип, як певне спів-буття. Таке визначення архетипу не є випадковим, оскільки воно дозволяє прослідкувати у музичній творчості, як саме, рухаючись у напрямку від інтуїтивного, позасвідомого осягання первообразів, архетипи перетворюється на загальнозначущі феномени відтворення структурної єдності «форми-ідеї».

У культурних процесах XX - початку XXI ст. феномен спів-буття постав як один 3 найбільш складних для розуміння i загадкових концептів сучасної думки, набув значення «своєрідного «маркеру» (О. Оришева) культури. Поняття спів-буття, як і архетипу, набуло в сучасному науковому дискурсі міждисциплінарного характеру, досліджується у філософії, культурології, літературознавстві, музикознавстві тощо. До феномену «співбуття» зверталися i звертаються А. Бадью, Ж. Бодрійяр, Ж. Дельоз, К. Лефор, Ж.-Л. Нансі, Ж. Рансьєр, М. Фуко та багато інших дослідників, але, головним чином, ця тема асоціюється із філософією пізнього М. Гайдеггера. Розглянемо зміст цього поняття більш докладно в культурологічному аспекті та спробуємо з'ясувати, чому архетип у векторі постмодерністичної думки розуміється як певне спів-буття.

\section{1. Поняття «спів-буття» у науковому дискурсі \\ М. Гайдегтера та Ж. Дельоза}

Спів-буття, за М. Гайдеггером, розглядається в космологічному значенні цього слова, як дещо, що трапилося і фактом свого існування - змінило світобудову. 3 точки зору німецького філософа, співбуття das Ereignis - це стан світу в точці «тут-і-тепер», в точці Dasein. У перекладі В. Бібіхіна - Dasein - це «присутність», «тут-буття». Мова йде саме про стан світу, а не про конкретні ситуації, які потрапляють в Dasein. Іншими словами, як каже В. Суханцева, саме можливість Dasein знаходитися в якості спів-буття у світі вихоплює його - Dasein 3 прокляття повсякденності і надає йому смисл ${ }^{1}$. Проблема Dasein, часу, повсякденності у М. Гайдеггера «зав’язані» на спів-бутті. Коли людина буттєіснує i одночасно спів-буттєіснує. Не у сенсі, що вона $\epsilon$ співучасником буття, а в тому, що людина породжує буттєвість, адже існує сама як одухотворене спів-буття в цьому бутті.

\footnotetext{
1 Суханцева В.К. Лекции по истории метафизики. URL : http://gzvon.pyramid.volia.ua/biblioteka/kafedra_filosofii/libph/sound/.
} 
У тексті доповіді М. Гайдегтера «Час і буття» співбуття (Ereignis) стає тим терміном, що призупиняє герменевтичну гру взаємного визначення буття та часу, «місцем», де вони можуть бути специфічно «локалізовані» і вихоплені думкою як такі: «Час і буття стверджуються у співбутті» ${ }^{2}$. При цьому саме це «місце» $\epsilon$ надзвичайно важко вловимим для осягнення думкою, оскільки співбуття концентрує в собі таку характеристику буття і часу як самовідняття, самоутримання. Таким чином, спостерігаючи перспективу, у якій можуть бути розпізнані буття і час, перебуваючи, у кінцевому підсумку, умовою наявності будь-якої конкретної присутності, спів-буття не мас власної локалізації. Російський дослідник А. Магун вважає, що перебуваючи «позначенням (граматичного) відсутнього або безособового суб'єкта (позначенням “es” у безособовому обороті “es gibt" - M.C.), Ereignis не може бути ані суб'єктом, ані субстанцією, ані взагалі чимось із сущого» ${ }^{3}$. Цю делокалізованність, «відсутність місця» можна розглядати як універсальну характеристику спів-буття, яка відноситься не тільки до складних теоретичних конструкцій, до художньої, зокрема музичної культури, але й до сфери повсякденного життя. Таким чином, спів-буття та спів-буттєвість $є$ певними екзистенційно-онтологічними вимірами життя кожної людини. Але на цьому функції спів-буття не закінчуються, оскільки будь-яке спів-буття розглядається як певний соціально-історичний досвід, обумовлено соціально-культурним контекстом.

Зовсім не випадково М. Гайдеггер визначив другий період своєї творчості «Vom Ereignis» («Про співбуття»). Він вважає цей етап буттєво-історичним, на відміну від першого - трансцендентногоризонтального. Тут у центрі уваги - Ereignis - провідний термін пізнього М. Гайдегтера. У роботі «Закон тотожності» М. Гайдеґгер уточнює, що слово «співбуття» постало з органічності мови. Ereignen (відбуватися, траплятися) спочатку означає eraugen, тобто помічати, наближати до себе у погляді, привласнювати. Як провідне слово, воно так само важко перекладається, як давньогрецьке «логос» або китайське «дао». На думку А. Магуна, слово «співбуття» означає лише те, що ми іноді називаємо «випадок» або «подія» Тому їх вживання можливе тільки в однині, адже те, що ним позначається, має місце як одиничне, але не як одноразове, а як єдине.

2 Хайдеггер М. Время и бытие : Статьи и выступления. Санкт-Петербург : Наука, 2007. С. 404.

3 Магун А. Отрицательная революция: к деконструкции политического субъекта. Санкт-Петербург : Изд-во Европейского ун-та в Санкт-Петербурге, 2008. C. 206. 
«Співбуття є внутрішньо мерехтливою сферою, у якій стикаються людина і буття у своїй сутності і досягають своєї сутнісної природи. Мислити Співбуття як Спів-буття, означає споруджувати мерехтливе у собі царство» ${ }^{4}$. На нашу думку, така «мерехтлива галузь» промовляє про зустріч глибинних, неусвідомлених людиною прошарків свідомості, а саме - архетипів - з Буттям. Відкривається завіса таїнства явища архетипів світу в якості спів-буття, завдяки їх попаданню у Dasein. Архетипи перетворюються на архетипові образи, які, на відміну від архетипів, вже мають наочно-чуттєвий характер і також постають у якості спів-буття. Але, ведучи мову про архетипи як спів-буття i архетиповий образ як спів-буття, слід зазначити, що це явища абсолютно різного порядку. Перший - містить виключно трансцендентний характер, а другий, за словами Гайдеггера, - буттєвоісторичний. Тому надалі ми будемо розрізняти ці дві форми співбуття - архетип і архетиповий образ 5 .

Треба відзначити, що М. Гайдеггер розглядає співбуття як сnівбуття з іншими (Mit-sein-mit-anderen). Один з розділів роботи «Буття i час» він так i називає «Співприсутність інших i повсякденне співбуття». У ньому німецький мислитель вказує на те, що префікс «сnів-» треба розуміти екзистенційно, а не категоріально. «На основі цього спільного буття-в-світі світ є завжди вже той, який я поділяю 3 іншими. Світ присутності є спільний-світ. Буття-в є спів-буття 3 іншими. Внутрішньосвітове само-по-собі-буття є співприсутність» ${ }^{6}$. Спів-буття - це наявність нас у бутті, наша присутність.

Цікаву, із цього приводу, думку висловила В. Суханцева. Вона вважає, що будь-яке спів-буття має темпоральну сторону, яка й постає найбільш складною для розуміння. Оскільки буття людини є буттям людини у часі, тоді слід уточнити, що й сама людина $\epsilon$ час. I якби не вона (людина), і не iii Dasein, то час не позначив би себе, оскільки

4 Хайдеггер М. Разговор на проселочной дороге. Москва : Высшая школа, 1991. С. 77.

${ }^{5}$ У своїх роботах К. Юнг розрізняє архетип і архетиповий образ. На відміну від архетипу (як первообразу), архетиповий образ має наявно-чуттєвий характер, це форма присутності архетипу у свідомості, яка трансформує його у символ. Тобто поєднує образ і смисл, який раціонально не експлікується. На нашу думку, за своєю сутністю архетиповий первообраз $\epsilon$ ідеальною, над-буттєвою константною моделлю, структурою, певним абсолютом, що втілюється у різноманітні форми духовного життя людини, наповнюючись на кожному історико-культурному етапі новими смисловими значеннями, перетворюючись на архетиповий образ. На відміну від архетипу, який як матриця має незмінне ядро, архетиповий образ більшою мірою $\epsilon$ мінливим та як «кореневище» (за постмодерністським визначенням) вбирає у себе певну кількість культурних значень та констант.

${ }^{6}$ Хайдеггер М. Бытие и время. Харьков : «Фолио», 2003. С. 142. 
єдине, що позначає час, що перебуває в часі, квапить час - це людина. Але тоді ми можемо втратити час, тому що людина розташовується в часі і має у своєму розпорядженні час ${ }^{7}$. Гайдеггерівське спів-буття $\epsilon$ збиранням часу воєдино. У цьому воно співставне з музикою, яка також збирає час воєдино. А це означає, що музика є спів-буттям, як на мікротак і на макро- рівнях. Протистояння об'єктивно плинному світовому часу, який нам ні про що не говорить і якого ми не відчуваємо - це є єдиною можливістю відчути цілісність часу на рівні Dasein.

Слід зазначити, що спів-буттєвість не залежить від щільності подій, що відбуваються. Адже всім відомо, що наше життя може бути перевантажене подіями, але у ньому може зовсім нічого не відбуватися. Треба сказати, що про невловимість спів-буттєвості і неможливості вписати iii y існуючий порядок речей говорили i говорять багато дослідників (М. Гайдегіер, Ж.Л. Нансі, Ж. Бодрійяр, Ж. Дельоз, М. Фуко). Саме в цьому й полягає складність опису спів-буття і співбуттєвості.

На думку видатного сучасного французького мислителя М. Фуко, найбільш вдалою спробою дослідити поняття «співбуття» стала робота Ж. Дельоза «Логіка смислу». За влучним зауваженням М. Фуко, «Логіку смислу» слід розглядати як «найсміливіший і найзухваліший із метафізичних (курсив наш - М.С.) трактатів - враховуючи основну умову, що замість скасування метафізики як заперечення буття, ми змушуємо останню говорити про над-буття (курсив наш - М.С.» ${ }^{8}$.

Ж. Дельоз вважав, що важлива складова спів-буття - модальність, оскільки спів-буття і у минулому, і майбутньому завжди повинно мати одну і ту саму модальність, «відповідно до якої воно роздріблює своє теперішнє до безкінечності. Якщо співбуття може бути у майбутньому i, реально - у минулому, то потрібно, щоб воно було відразу i можливим, i реальним, оскільки воно водночас розподілено між ними» ${ }^{9}$. Міркування французького філософа про модальність співбуття якнайкраще вкладається у розуміння архетипу як певного співбуття та його часовий модус, а саме - спів-присутності у минулому, теперішньому i майбутньому. Така думка $\epsilon$ співзвучною 3 ідеєю «вічного повернення» Ф. Ніцше.

Слід зазначити, що метафізична концепція Ф. Ніцше «вічного повернення», про яку він сам казав, як про безумовний та безкінечний кругообіг всіх речей, що повторюється, набуває нових значень у пост-

7 Суханцева В.К. Лекции по истории метафизики. URL : http://gzvon.pyramid.volia.ua/biblioteka/kafedra_filosofii/libph/sound/.

8 Фуко M. Theatrum philosophicum / Делёз Ж. Логика смысла. Москва : Академический Проект, 2011. С. 443.

9 Делёз Ж. Логика смысла. Москва : Академический Проект, 2011. С. 51. 
культурі, зокрема, розуміється як справжня нескінченна втеча. Здебільшого це втеча у минуле. Таку «втечу в часі» Жан Бодрійяр пояснює, як певний метафоричний відхід в історичне минуле. Це є наївним сподіванням, що версія історичного минулого є «легендою», яка a priori характеризується коефіцієнтом достовірності. Утім, оскільки їі специфічне переживання виявляє залежність від доби та стилю, вона сама $\epsilon$ функцією середовища та часу. Все минуле залучається в обіг, у цикл вжитку - екрани заповнилися знаками та ідолами, які «відсилають» до чогось, неважливо, справжнього чи вигаданого» ${ }^{10}$. Проте втеча від сучасності та занурення у минуле не вирішує питань сьогодення. А тому подібні «походи в історію» все ж мають на меті вирішення проблем цілком сучасних. Звернення до історії культури та використання різних жанрово-стильових та образних проявів минулого отримують специфічне переломлення. У музичному мистецтві це призводить до алюзійності, колажності, полістилістики тощо. Архетипові образи «стосуються переважно найближчого шару історії та культури або ж больових точок колективного несвідомого < ... “ “вісь апеляцій” утворюється оголеним нервом колективної історичної пам'яті»" ${ }^{11}$.

Із точки зору Ж. Дельоза, «вічне повернення»- це не теорія якостей i їх циклічних трансформацій; це теорія чистих проявів спів-буття і їх лінійного i поверхневого згущення. «Вічне повернення», за мислителем, зберігає вибірковий смисл i прив'язано до неспівможливості, а саме таким чином, що воно представлене за допомогою форм, які перешкоджають його конституюванню i функціонуванню. «Контрздійснюючи кожне співбуття, - пише автор, актор-танцюрист виявляє чисте співбуття, що комунікує 3 усіма іншими проявами співбуттями, і повертається до самого себе через всі інші прояви співбуття і 3 усіма іншими проявами співбуття» ${ }^{12}$.

Тому, за Дельозом, Буття - це те, що «завжди висловлюється про різницю; це - Повторювання [Revenir] різниці» (М. Фуко). Однак, якщо щось і повторюється, так це - час. За влучним зауваженням М. Фуко ${ }^{13}$, теперішній час подібний розщепленню стріли, яка встромляючись, розщеплює тріщину далі, весь час, змушуючи останню відхилятися від прямого шляху в обидві сторони, - нескінченно повторюючись.

${ }^{10}$ Бодрийяр Ж. Система вещей. Москва : «РУДОМИНО», 1999. С. 90.

11 Зубавіна І.Б. Кінематограф незалежної України: тенденції, фільми, постаті. Київ : ФЕНІКС, 2007. С. 72.

12 Делёз Ж. Логика смысла. Москва : Академический Проект, 2011. С. 235.

13 Фуко М. Theatrum philosophicum. ДелёзЖ. Логика смысла. Москва : Академический Проект, 2011. 


\section{2. Архетиповість часового модусу спів-буття у роботах Ж.-Л. Нансі «Буття одиничне множинне» та Ж. Дельоза «Логіка смислу»}

Сучасний французький дослідник Ж.-Л. Нансі має практично таку саму точку зору, що й Ж. Дельоз. У роботі «Буття одиничне множинне», розмірковуючи над ніцшевською ідеєю «вічного повернення», він говорить про кругообіг, який відбувається у всіх напрямках, оскільки впевнений, що «смисл $є$ повторення миттєвості і ніщо більше, як це повторення <...> це повторення вже міститься у позначенні миттєвості, у цьому твердженні-запитуванні (re-petitio), охопленому в невловимості миттєвості, фіксуючи минущість сьогодення і спливаючи разом 3 ним, у твердженні, залишеному у самий момент власного руху» ${ }^{14}$.

Зазначу, що ніцшевська ідея «вічного повернення» у тлумаченні Ж. Дельоза і Ж.-Л. Нансі досить м'яко «перекладається» на мову музики, особливо сучасної. Тільки музика, на відміну від інших видів мистецтв, здатна «охоплювати» в одну єдину мить все й одразу, поєднуючи минуле, сьогодення i, до певної міри, продукувати майбутнє. Тому підкреслю, що витоки композиторської творчості містяться у їх архетиповому буттєво-онтологічному зрозумінні. Отже, розмірковуючи про «вічне повернення» у музиці, слід сказати про вічне теперішне, що постає як «недостатня наповненість» (М. Фуко), i, водночас, вічне постає «як недостатня єдність: (множинна) вічність (усуненого) теперішнього» ${ }^{15}$ (М. Фуко).

Один із прикладів такого «вічного повернення», «повторення різниці» у композиторській творчості слід назвати «Мардонги»- цикл п’єс для фортепіано сучасного українського композитора С. Луньова. Драматургічна концепція цього циклу полягає в тому, щоб, на думку самого автора, «передати своє відчуття від усвідомлення присутності мардонгів, як конкретних композиторів, так і їх конкретних творів, а також деяких жанрів і колективних мардонгів композиторських шкіл (зокрема: віденської та нововіденської)» ${ }^{16}$ (С. Луньов). У назвах частин імена не анонсуються. Для композитора абсолютно принциповим стають тільки дати народження кожного композитора у якості назв частин. Кожна дата символізує «вектор, що виходить 3 точки у безкінечність» (С. Луньов). Цей цикл можна назвати архетиповою стилізацією творчості різних композиторів. В. Луньов апелює до

${ }^{14}$ Нанси Ж.-Л. Бытие единичное множественное. Мн. : Логвинов, 2004. С.18-19.

15 Фуко М. Theatrum philosophicum. Делёз Ж. Логика смысла. Москва : Академический Проект, 2011. С. 468.

16 Латковська Н. Інтертекстуальність як фактор організації художнього простору у фортепіанному циклі «Мардонги» С. Луньова. Київ : Київське музикознавство. Збірка статей. Вип. 39, 2011. С. 15. 
колективної історичної пам'яті, до чистих архетипових проявів співбуття (спів-буттєвих подій), які у процесі комунікації 3 іншими повертаються до самих себе через всі інші прояви співбуття і з усіма іншими проявами співбуттями, отримуючи яскраве втілення в музичній інтерпретації українського композитора.

Повертаючись до розуміння спів-буття Ж. Дельозом, слід зазначити, що для нього ідеальне спів-буття є сингулярність, тобто одиничність цього спів-буття. Або, як уточнює автор, скоріше сукупність сингулярностей, сингулярних точок, що характеризують математичну криву, фізичний стан речей, психологічну або моральну особистість. Сам Дельоз наполягає на тому, що сингулярність нейтральна і навіть ідеальна, вона не повинна змішуватися ні з поняттям особистості, ні 3 поняттям індивідуальності, оскільки індивід має усвідомлювати себе як спів-буття, а здійснюване в ньому спів-буття - як іншого індивіда, «ніби прищепленого до нього». На думку Ж. Дельоза, якщо це вдається, то розуміння, бажання і уявлення індивідом спів-буття відбувається через розуміння і бажання всіх інших проявів спів-буття як індивідів і уявлення всіх інших індивідів як проявів спів-буття. Тобто таке спів-буття $\epsilon$ гайдеггерівським спів-буттям 3 іншими (Mit-sein-mit-anderen). Як пише Ж. Дельоз: «Кожна індивідуальність уподібнювалася б при цьому дзеркалу для конденсування сингулярностей, а кожний світ - перспективі у такому дзеркалі» ${ }^{17}$.

Ще великий романтик Новаліс стверджував, що існує два типи проявів спів-буття (ходу подій): один - ідеальний, інший - реальний i недосконалий. Але для Ж. Дельоза ця відмінність проходить не між двома типами проявів спів-буття, а скоріше, «між співбуттям, за своєю природою ідеальним, і його просторово-часовим здійсненням у стані речей. Воно між співбуттям і пригодою» ${ }^{18}$. Перефразуючи французького дослідника, можна сказати, що архетипи як певні прояви спів-буття $є$ також ідеальними сингулярностями, вони володіють вічною абсолютною істиною, та ніколи їх часом не є теперішнє, що змушує їх існувати і відбуватися. Вони (архетипи) це «безмежний Еон, Інфінітив, де мешкають та стикаються прояви співбуття» ${ }^{19}$ (Ж. Дельоз).

Перефразуючи Ж. Дельоза, зазначу, часовий модус архетипу співбуття промовляє нам про те, що спів-буття не має теперішнього. Однак не варто сприймати таку заяву Дельоза примітивно, оскільки теперішнє, і це особливо відчутно у музиці, відступає та лине вперед у двох смислах-напрямках водночас, постаючи у якості одвічного об'єкта

\footnotetext{
17 Делёз Ж. Логика смысла. Москва : Академический Проект, 2011. С. 234.

18 Там само. С. 76-77.

19 Там само.
} 
подвійного запитування: що ось-ось станеться? що ось-ось сталося? «Болісна сторона чистого співбуття у тому, що воно $є$ дещо, яке ось-ось відбулося або ось-ось відбудеться, але ніколи не $є$ те, що ось зараз відбувається» ${ }^{20}$.

Транспонуючи думку Дельоза на сферу музичної творчості, можна сказати, що певне «X» є темою того, що тільки-но відбулося, - це тема будь-якого музичного жанру, приміром, «вальсу»; а «х», це те що осьось має статися, - це тема іншого жанру, наприклад, «мазурки». Чисте співбуття - це одночасно i вальс, i мазурка, «але ніколи не актуальність. Саме у цьому сенсі прояви співбуття суть знаки» ${ }^{21}$.

Ще одне 3 положень, яке викликає зацікавленість у роботі Ж. Дельоза - це взаємовідношення Спів-буття та Великого часу - Еону, де кожне спів-буття адекватно всьому Еону, кожне спів-буття знаходиться у взаємодії з усіма іншими його проявами, в одну єдину мить формуючи одне і те саме Спів-буття. А саме «співбуття Еону, де вони володіють вічною істиною. У цьому таємниця співбуття: воно існує на лінії Еону, але не заповнює його». Він, так би мовити, розуміє чисте спів-буття у його вічній істині - незалежної від його просторовочасового здійснення - «як те, що завжди ось-ось станеться або вже відбулося на лінії Еону» ${ }^{22}$.

У музиці, з нашої точки зору, через архетипи найбільш яскраво проявляється множинна одиничності буття сущого. Архетип $\epsilon$ витоком музичного творіння. Він (архетип) інваріантний і варіативний одночасно. Буття архетипу вже від початку говорить про його інакшість по відношенню до інших його проявів. Промовляючи словами Ж.-Л. Нансі, «те, що становить інакшість (altérite) іншого - це його буття-початок (буття-джерело - М.С.). У свою чергу, те, що становить відначальність витоку, це його іншо-буття, але це буття $є$ іншим, ніж все суще постає для всього сущого в проходженні $i$ через все суще» ${ }^{23}$. Таким чином, Ж.-Л. Нансі доходить висновку, що відначальність початку-витоку, як певна властивість, не може відрізняти суще від всіх інших сущих, оскільки «це суще повинно було б бути іншим по відношенню до самого себе, щоб, у свою чергу, мати свій початок» ${ }^{24}$.

На думку Ж.-Л. Нансі, іншобуття витоку-початку - $\epsilon$ не однаковість «інакшого-ніж-світ». Для французького мислителя, мова йде про «щось Інше (неминуче «велике Інше»), ніж світ, мова йде про інакшість, або

\footnotetext{
${ }^{20}$ Делёз Ж. Логика смысла. Москва : Академический Проект, 2011. С. 88.

21 Там само.

${ }^{22}$ Там само. С. 90.

${ }^{23}$ Нанси Ж.-Л. Бытие единичное множественное. Минск : Логвинов, 2004. С. 29

${ }^{24}$ там само.
} 
зміну світу» ${ }^{25}$. Ідея Ж.-Л. Нансі про те, що «зовнішнє» (le dehors) витоку-початку знаходиться «всередині» (le dedans) більш внутрішній (intérieur), ніж найграничніше «внутрішнє», більш внутрішній, ніж інтимність світу та інтимність кожного «я». Відтак якщо інтимність $\epsilon$ граничним співпадінням 3 самим собою, то виток-початок «є розсовування спів-падання як такого. Це $є$ спів-існування витокупочатку «в» самому собі, тобто спів-існування витоків-початків» ${ }^{26}$. Фактично Ж.-Л. Нансі продовжує роздуми про витоки художнього творіння у контексті роздумів М. Гайдеггера.

Треба відзначити, що сам Ж.-Л. Нансі говорить про те, що слово «інтимність» вживається не випадково і більш за все не стільки як ставлення до себе, скільки як відносини між багатьма. Тому французький мислитель підсумовує, що наше спів-буття як буття-з-багатьма - це не випадковість, воно не є вторинним, не «розсіює» первинну сутність, утворюючи «власні та необхідні статус і зміст відначальної інакшості як такої. Множинність сущого лежить в основі буття» ${ }^{27}$.

Ведучи мову про архетипи як про спів-буття, необхідно відзначити, що кожен архетип безумовно передбачає «буття-з-багатьма» іншими архетипами, що власне і є його «споконвічною інакшістю». Тобто за всією своєю інваріантністю та споконвічною абстрактністю архетип $є$ феноменом потенційним і в «бутті-з-багатьма» постає варіативним. Архетип у музиці $є$ витоком не тільки музичного розгортання, але й, переінтоновуючи М. Арановського, «його семантики». Крім того, архетип в музиці (як певний первообраз, ейдос) може бути представлений не тільки у вигляді музичного образу, музичної інтонації, але й у вигляді одного звуку, «як слухового уявлення» (М. Арановський).

М. Арановський відзначає, що «звуки, слухові уявлення з'являються на світ апріорі навантаженими тими значеннями, які вони отримують в рамках граматик. Тільки в граматиках ці відносини постають як абстрактні, потенційні, а переходячи в текст, перетворюються у контекстуальні i можуть надто відрізнятися від висхідних, граматичних» ${ }^{28}$. Тому він стверджує, що звук як елемент граматики за своєю смисловою навантаженістю - однозначний. Але, як тільки звук потрапляє у контекст «буття-з-багатьма», «він потрапляє на перетин полів відразу багатьох граматик, стає носієм множинних системних зв'язків $і$ відносин» ${ }^{29}$. Безумовно, тут мова йде не просто про один звук.

${ }^{25}$ Нанси Ж.-Л. Бытие единичное множественное. Минск : Логвинов, 2004. С. 32.

${ }^{26}$ Там само.

${ }^{27}$ Там само. С. 33.

${ }^{28}$ Арановский М. Г. Музыка и мышление / Музыка как форма интеллектуальной деятельности. Москва : Книжный дом «ЛИБРОКОМ», 2009. С. 42.

${ }^{29}$ Нанси Ж.-Л. Бытие единичное множественное. Минск : Логвинов, 2004. С. 34. 
Приклад одного звуку найбільш зручний, оскільки звук $є$ найменшим музичним елементом і його можна розглядати як певний первинний музичний архетип. Потрапляючи у смисловий контекст музичного тексту, звук як архетип починає взаємодіяти 3 іншими звукамиархетипами, створюючи високий ступінь «семантичної багатозначності кожного звуку» (М. Арановський). Таким чином, підкреслимо, що у музиці за допомогою архетипів найбільш яскраво проявляється множинна одиничність буття сущого .

Якщо виток-початок непереборно множинний, якщо він $\epsilon$, на думку Нансі, складена нескінченну кількість разів і нескінченно примножена, інтимність світу, то розмови про недоступність витоку-початку набувають інший сенс. Експлікуючи ці роздуми на предмет нашого дослідження, відзначимо: оскільки архетип є витоком-початком, то він існує спільно з іншими архетипами-витоками, як розподіл витокупочатку. Отже, за Нансі, ми досягаємо його. Французький мислитель відзначає той факт, що «ми підходимо до нього, ми знаходимося біля краю, у самій безпосередній близькості, на порозі, ми торкаємося витоку-початку» ${ }^{30}$. Насправді, за влучним висловом Ж. Батая, «ми добираємося <...> до нього. Цей вислів французького вченого i письменника утверджує миттєву втрату доступу до витоку-початку. Ніби полемізуючи, Ж.-Л. Нансі вважає, що доторкнутися до витокупочатку означає не втратити його, а бути справді виставленим йому напоказ. Мабуть, все відбувається між втратою і здобуттям.

Підкреслюючи вираз «прихованого доступу у його власній відкритості і саме тому «не імітуючого», не переданого, не перекладеного» ${ }^{31}$, Ж.-Л. Нансі відзначає певну абсолютну точку «перекладу, передачі або переходу з витоку до витоку» ${ }^{32}$. Подібно до того, як види мистецтва роз'єднані між собою, вони, водночас, утворюють «абсолютну точку перекладу». Так і архетипи в музиці роз'єднані між собою, але, одночасно, множинно одиничні i, попри відмінності, у певний момент у певній точці відбувається «зустріч», досягнення Абсолюту, витоку художнього твору.

Ведучи мову про виток-початок, як про найважливіше у мистецтві і про «те, що робить людину художником світу, тобто тим, хто демонструє світ для світу» ${ }^{33}$, Нансі стверджує, що все це не стосується естетичних категорій «прекрасного» або ж «піднесеного», це не «скінченність без кінця», «не естетичне судження», «не прояв почуттів» i не «втілення істини». Таке твердження якнайбільше відповідає сучасному розумінню мистецтва, зокрема й музичного.

\footnotetext{
${ }^{30}$ Нанси Ж.-Л. Бытие единичное множественное. Минск : Логвинов, 2004. С. 32.

${ }^{31}$ Там само. С. 33.

32 Там само. C. 33 .

${ }^{33}$ Там само. С. 34.
} 
Композитор є тим, хто у своїх творіннях саме «демонструє світ для світу»: чи то свій, чи то світ Іншої людини, чи то світ як космос, або ж світ сакральний для світу буденного. Така «репрезентація» $\epsilon$ i одночасний доступ до віддаленого витоку-початку, й відрив від нього; тут відбувається множинне доторкання до одиничного витоку-початку, як «наслідування природі».

Хотілося б зупинитися на роздумах Ж.-Л. Нансі про мистецтво, у яких він розмірковує про його космогонічність, що виявляється у множинності, розрізненості, дискретності, кольоровому мазку, тембрі, фразі, спалаху, запаху, співі або застиглому па, оскільки вона (космогонічність) «є народженням світу (а не створенням системи)». Для Ж.-Л. Нансі поняття світу пов'язане $з$ такою безліччю світів, скільки потрібно для створення одного світу, оскільки саме в ньому людина може досягти лише самого себе й світ. У цьому французький вчений фактично проводить паралель з ідеями М. Гайдеггера і називає це, вживаючи гайдегтерівську термінологію, «скінченність». Але для Ж.-Л. Нансі така «скінченність» є нескінченною одиничністю смислу, доступом до істини. I що, на перший погляд, може видатися парадоксальним, «скінченність», за Нансі, «є витоком-початком, тобто вона $\epsilon$ нескінченністю начал. «Виток» означає не те, звідки виник світ, але прибуття, шоразу єдине, кожної присутності світу» ${ }^{34}[249$, с. 35]. Фактично Ж.-Л. Нансі цікавить виток-початок будь-якого одиничного сущого у його повсякденному бутті, як присутність у цьому одиничному сущому всього величезного світу. Як і будь-який архетип містить у собі виток-початок всього світу, так і світ несе в собі частку кожного архетипу. Так виникає цілісне сприйняття світу, буття.

У процесі роздумів французький вчений приходить до одного 3 головних висновків свого дослідження, який багато в чому збігається 3 ідеєю М. Гайдептера про те, що «одиничне множинне буття» означає існування буття тільки за умови його «спів-сутності», або ж спів-буття - буття-з-багатьма. Немає потреби говорити про комунікативну функцію архетипів, про їх буття-з-багатьма. Отримавши першопоштовх ще у композиторському задумі, одиничність архетипу переростає у його множинність. Творіння композитора, що отримало хоча б найменшу інтерпретацію, навіть самого автора, не кажучи вже про «прочитання» цього творіння виконавцем і слухачами, говорить вже про певне ми. Сам Ж.-Л. Нансі проводить розмежувальну риску між «и говорить - і ми говоримо ${ }^{35}$. Для нього - це унікальне спів-буття, чия одиничність і єдність полягає у множинності. Префікс «спів-» якраз визначає єдність одиничності того, що є в цілому. Але при цьому,

\footnotetext{
${ }^{34}$ Нанси Ж.-Л. Бытие единичное множественное. Минск : Логвинов, 2004. С. 35.

${ }^{35}$ Там само. С. 20.
} 
Ж.-Л. Нансі цілком справедливо розрізняє абстрактне поняття «всі ми» і індивідуальне «я», між якими розташовується «ми інші» Ф. Ніцше. Завдяки такому «ми інші» усувається опозиція окремого i всезагального.

\section{3. Спів-буття як діалог у науковому дискурсі М. Бахтіна і Г. Гадамера}

Тут напрошується паралель 3 роботами видатного російського дослідника, семіотичної школи - Михайла Бахтіна. Незважаючи на те, що у силу історичних, а більше політичних обставин, пов'язаних із «замкненістю» радянського соціокультурного простору, М. Бахтін не мав можливості повноцінно ознайомитися з роботами М. Гайдеггера та Ж.-Л. Нансі, у своїх дослідженнях він висловлює думки, багато в чому схожі $з$ ідеями, висловленими німецьким і французьким вченими. А саме: одним 3 основних понять у дослідженнях М. Бахтіна також постає поняття «співбуття». Але для Бахтіна «співбуття»- це, перш за все, діалог: діалог культур, діалог автора 3 читачем, діалог 3 нададресатом (Космосом, Богом, Абсолютом, Вселенським Розумом), діалог автора із самим собою та ін.

Введення поняття співбуттєвості зближує ідеї М. Бахтіна $з$ цілою системою понять, які істотно змінили сучасний погляд на природу людини, а саме - іiі життя, екзистенцію, переживання, Dasein та інше. М. Бахтін пише: «Ствердити факт своєї єдиної незамінної причетності до буття - означає увійти у буття саме там, де воно не дорівнює собі самому - увійти у співбуття буття (курсив наш - М.С.)» ${ }^{36}$. Істотно, що М. Бахтін принципово не визнає розуміння буття, якому «байдужий центральний для мене факт моєї єдиної дійсної причетності до буття» ${ }^{37}$. Бахтінівське сприйняття людського буття-співбуття базується на його фундаментальній онтології як етиці: описувати буття-співбуття так, «як його знає вчинок», значить показувати його як буття з іншими, тобто спів-буття, тобто діалогічно. I тоді активна причетність особистості буттю-співбуттю виявляється справою іiі морального ставлення до іншого.

Крім того, спів-буття М. Бахтіна $є$ «естетичним співбуттям», яке стало основоположною позицією автора у роботі «Проблема автора i героя у російській літературі». Для російського дослідника принципово важливим є взаємозв'язок автора і героя як учасників «естетичного співбуття». У контексті нашого дослідження, спів-буття за М. Гайдегером, Ж.-Л. Нансі та М. Бахтіним, як «буття-з-багатьма», зосереджує увагу на ціннісному характері будь-якого естетичного спів-

\footnotetext{
${ }^{36}$ Бахтин М. М. К философии поступка. Киев : «Next», 1994. С. 43.

${ }^{37}$ Там само. С. 17.
} 
буття. Це ще раз підкреслює важливу роль архетипів, проблему їх вибору, як вчинку (за Бахтіним), його (вчинку) активної причетності до буття-співбуття, що структурується «через мене та інших», а, отже, i «заданість бути відповідальним» (М. Бахтін).

Як влучно зауважив російський культуролог Г. Дьяконов, вчинок, як «співбуття здійснюваного буття», уявляє собою «незлитне співпроникнення» індивідуального буття у процесі його становлення i своєрідного зрізу культурно-історичної ситуації, що віддзеркалює картину буття людини. Стає очевидним, що екзистенційне розуміння природи людського вчинку, як про-явлення архетипів у бутті, дозволяє зайняти «позазнаходжувану точку зору щодо діяльнісно-прагматичного та ідеально-споглядального, інтелігібельно-рефлексивного розуміння» ${ }^{38}$ сутності і природи архетипів як спів-буття у житті людини та її причетності до буття і світу.

У даному випадку бахтінівська концепція онтології як етики багато в чому співзвучна 3 герменевтичною концепцією Г. Гадамера. Останній розуміс спів-буття 3 точки зору традиції. У цьому питанні Гадамер виходить 3 метафізичного розуміння буття, а саме - розрізнюе модуси буття: незмінно одвічне та божественне; те, що постійно знаходиться у русі - природа; етос, який пов'язує себе моральними законами - людина. Так, за Гадамером, традиція метафізики є понад всім, а ії головні теми (метафізика природи, метафізика нравів, що існували ще за часів Канта) $є$ специфічним поєднанням пізнання Бога та моральної філософії.

Міркування Г. Гадамера про спів-буття у контексті герменевтики повністю збігаються 3 діалогічною позицією М. Бахтіна. Для Г. Гадамера герменевтичне розуміння спів-буття нагадує міст через прірву між нашим духом і духом інакшим, i «відкриває нам чужинність чужого духу». Таке відкриття «чужого», перш за все, означає «почути те, що до нас промовляють», а не тільки «історичну реконструкцію «світу», у якому художній твір розгортав свою первісну значущість i функцію» ${ }^{39}$.

Діалог буття - спів-буття для М. Бахтіна і Г. Гадамера полягає не у тому, щоб ототожнити себе з автором і, тим самим, «подолати відстань між його і своїм досвідом, а в тому, щоб, усвідомлюючи непереборність цієї відстані, застосувати досвід автора щодо себе» ${ }^{40}$. Іншими словами, мету інтерпретації тексту як архетипу, як спів-буття Г. Гадамер вбачає не у «відтворенні», а у «створенні» смислу. Або, цитуючи В. Малахова,

${ }^{38}$ Дьяконов Г. В. Этика поступка и концепция «Другого» М. М. Бахтина - исток и предпосылка психологической онтологии диалога. URL : http://www.hpsy.ru (дата звернення 16.01.2021).

${ }^{39}$ Гадамер Г. -Г. Актуальность прекрасного. Москва : Искусство, 1991. С. 262.

40 Малахов В. С. Философская герменевтика Г. Г. Гадамера. Гадамер Г. Г. Актуальность прекрасного. Москва : Искусство, 1991. С. 329. 
основне завдання німецький мислитель бачить «не в реконструкиіі (задуму), а в конструкції (смислу)» ${ }^{41}$. Це означає, що кожен автор і його інтерпретатори «витягують на поверхню» або ж «конструюють» безмежну кількість архетипових кодів, які отримали свій «формуляр» у тому чи іншому культурно-історичному і особистісному контексті. Таким чином, на думку Б. Успенського, «проявам співбуттям надається значення: ТЕКСТ проявів співбуття прочитується соціумом» ${ }^{42}$. У такому випадку, продовжуючи думку Б. Успенського, можна сказати, що такий процес $\epsilon$ породженням нових фраз будь-якою «мовою» і прочитанням їх суспільним адресатом (соціумом).

Крім того, той, хто хоче зрозуміти певний культурний текст 3 погляду його архетиповості, кажучи словами Г. Гадамера, «пов'язує себе 3 предметом, про який свідчить стародавній переказ, і або перебуває у контакті з традицією, зсередини якої звертається до нас ця оповідь, або прагне віднайти такий контакт» ${ }^{43}$. На думку Г. Гадамера, місце, уготоване нам традицією, завжди знаходиться між «чужістю i близькістю». Але найголовніше, що в основі такого проміжку між «чужістю і близькістю» лежить часова дистанція, «це <... основа співбуття (курсив наш - М.С.), у якому закорінене наше сьогоднішне розуміння. <..> Цей часовий проміжок заповнений послідовністю проявів співбуття традиції, у світлі якої і постає для нас весь переказ. Тут можна говорити про справжню продуктивність того чи іншого співбуття» ${ }^{44}$.

I М. Бахтін, і Г. Гадамер, і М. Гайдегтер розуміли, наскільки $є$ безсилою наша наукова свідомість у своїх судженнях про сучасне мистецтво з точки зору спів-буття і спів-буттєвості, наскільки «відчуває себе почасти щонайневпевненішою» (Г. Гадамер), оскільки явно загострюється контраст між новими формами i старими. I тому сьогодні відбувається «переворот» у світогляді, світосприйнятті, світовідчутті і світовідношенні людини. Архетип як спів-буття розглядається нами як багатовимірний об'єкт, який ми бачимо тільки як його окремі проекції, видимим лишається тільки верхівка цього айсбергу. Саме тому то й не можна заперечувати новітні художні напрями, оскільки вони, як певне спів-буття, репрезентують множинність описів, образів, зразків архетипів всієї світової культури, як не можна i заперечувати все, що стало надбанням, досвідом культури у вигляді традицій. Для великих мислителів не існує

${ }^{41}$ Малахов В. С. Философская герменевтика Г. Г. Гадамера. Гадамер Г. Г. Актуальность прекрасного. Москва : Искусство, 1991. С. 329.

42 Успенский Б.А. Семиотика истории. Семиотика культуры. М. : Издательство «Гнозис», 1994. Т. 1. С.35

${ }^{43}$ Гадамер Г. -Г. Актуальность прекрасного. Москва : Искусство, 1991. С. 80.

44 там само. 
протиставлення «минулого» й «теперішнього». Їх уявне протистояння «знімається» завдяки феномену спів-буття, оскільки «співбуття $\epsilon$ одночасність, спів-часовість «тоді» й «тепер» <... Якщо вже без звичного членування історичного часу на «минуле» й «сьогодення» не обійтися, то співбуття - це спосіб буття «минулого» в «сьогоденні» ${ }^{45}$.

Таким чином, спів-буття $\epsilon$ нашою присутністю або співприсутністю у Dasein, а «спів-буття традиції» або ж «спів-буття архетипу» - це присутність (спів-присутність) історії у сучасності, яку Г. Гадамер називає «досвідом мистецтва» й, завдяки якому не переривається «досвід історії», іiї (історії) континуум. Отже, для того, щоб зрозуміти ті чи інші архетипи як спів-буття, їх потрібно проаналізувати, але щоб їх досліджувати, потрібно вже володіти їх розумінням, тим, що Г. Гадамер називає «передрозумінням» (Vorverständnis)». Відтак, герменевтика Г. Гадамера «переводиться 3 “методологічного плану у онтологічний” (В. Малахов), стверджуючи торжество, свято метафізики, тріумф буттєвості, а точніше - співбуттєвості, у тому числі й архетипів.

\section{ВИСНОВКИ}

Однією з ознак та теоретичних досягнень сучасної культури можна назвати онтологізацію розуміння та визначення статусу феномену «спів-буття», який розглядається у контексті архетипів. За М. Гайдегґером, спів-буття (Er-eignis) $\epsilon$ одним із екзистенційноонтологічних вимірів життя кожної людини, наявності іiі у бутті, присутності або спів-присутності. Завдяки розумінню архетипу як співбуття постає можливість дослідити особливий духовний, моральноцүіннісний досвід, щуо охоплює иілісність людського існування, всієї культури, Буття як иілого.

Поняття «спів-буття» дозволяє провести взаємозв'язок між часом та здатністю людської душі «простерти себе» (за Блаженним Августином) у минуле та майбутнє, відчувши їх часовий вимір, що повністю відповідає сутності музики. У цьому сенсі архетипи як спів-буття можна порівняти 3 ідеєю ніцшевського «вічного повернення», як «безкінечного кругообігу», яка була розвинута багатьма дослідниками (Ж. Бодрійяр, Ж. Дельоз, Ж.-Л. Нансі, М. Фуко). Серед найпродуктивніших, виділимо тут ідею поєднання у архетиповості спів-буття різнорівневих прошарків буттєвості - як ідеальної, так і реальної. Звідси - і співвідношення архетипу-спів-буття і Великого часу, коли архетип як ідеальне співбуття існує у вічному Еоні, вічній Істині.

45 Малахов В. С. Философская герменевтика Г. Г. Гадамера. Гадамер Г. Г. Актуальность прекрасного. Москва : Искусство, 1991. С. 335. 
Маючи варіативний потенціал, архетип як спів-буття $\epsilon$, за Ж.-Л. Нансі, множинною одиничністю буття сущого, створює комунікативний досвід. У музичній творчості такий досвід найбільш яскраво прослідковується у тріаді композитор-виконавець-слухач, коли абстрактний, потенційний текст твору композитора, як певний архетип-спів-буття, на різних рівнях (від одного звуку, тону, тембру до різноманітних моделей композиторської творчості, жанру, стилю) має безліч конотацій. Останні, у свою чергу, містять семантичне архетипове підгрунтя для «прочитання» цього тексту виконавцем та слухачем, створюючи фреймові смислові контексти. Тобто архетип $є$ за своєю сутністю «відкритим текстом» (за У. Еко). У процесі комунікації архетипи у музичному творі репрезентують світ композитора, який намагається дотягнутися, доторкнутися до витоку, первообразу цього творіння, конструюючи смисли. Композитор постійно «розкодовує» смисли первообразів. Тому ми говоримо про космогонічність і навіть божественність композиторської творчості, спрямовану на утворення цілісності сприйняття світу, його спів-буттєвість. Отже, архетипи як спів-буття $\epsilon$ багатовимірними та уявляють собою множинність описів, образів, ликів культури.

\section{АНОТАЦІЯ}

Розглянуто феномен «архетип» як засадничу основу будь-якого «спів-буття», а також «спів-буття» - 3 точки зору його архетиповості. Зазначено важливість розуміння «співбуття» як спів-буття з іншими, або діалог, коли префікс «спів-» розуміється онтологічноекзистенційно (за М. Гайдеггером) та з точки зору онтології як етики (за М. Бахтіним), що дає змогу говорити про «понад-буття» (за М. Фуко). У цьому контексті розглянуто поняття «образ иілісності» (М. Гайдеггер), що розуміється не просто як художній образ, а як узагальнений образ спів-буття архетипового первообразу та архетипового образу. Визначено буттєвість архетипу як «спів-буття» в композиторській творчості, що досліджено як «множинна одиничність буття сущого» (за Ж.-Л. Нансі), оскільки буття архетипу первісно говорить про його «інакшість» по відношенню до інших архетипів. Ураховуюче такий підхід, обгрунтовано не лише виток, а й семантичне розгортання архетипів у музиці. Доведено, що архетипи є базовими семантичними одиницями музики, що виявляють себе як спів-буття на «мікро-», так і на «макро-» рівнях - від звуку, тону, тембру, ритму, ладу, гармонії, мелодії тощо до музичних форм, жанрів, стилів в усій множині їх проявів. 


\section{SUMMARY}

Modern culture is characterized by an open, non-classical perception of the world, the growth of mosaicism, oversaturation of cultural forms. On the one hand, the artistic consciousness of the XXI century feels the structurelessness and vagueness of modern reality, the impossibility of explaining it with existing poetic, musical, philosophical formulas. On the other hand, the artist's irresistible desire to turn chaos into order remains, based on global ideas about the possibilities of his art. In this regard, it is especially important to find the primary, internal foundations that would not only produce a variety of historically complex art forms, but would also be the equivalent of universal, cultural. One of such bases, the most important elements, universals of culture are archetypes.

One of the features and theoretical achievements of modern culture can be called the ontologization of understanding and determining the status of the phenomenon of "co-existence", which we consider in the context of archetypes. According to M. Heidegger, co-existence (Er-eignis) is one of the certain existential and ontological dimensions of each person's life, its existence in being, presence or co-presence. But the functions of coexistence do not end there, because any co-existence is considered as a certain socio-historical experience. Thanks to the understanding of the archetype as co-existence, it is possible to explore a special spiritual, moral and value experience that encompasses the integrity of human existence, the whole culture, Being as a whole.

The concept of "co-existence" allows us to make a relationship between time and the ability of the human soul to "spread itself" (according to Blessed Augustine) into the past and future, feeling the temporal dimension, which fully corresponds to the essence of music. In this sense, archetypes as co-existence can be compared with the idea of Nietzsche's "eternal return" as an "infinite cycle", which was developed by many researchers (J. Baudrillard, G. Deleuze, J.-L. Nancy, M. Foucault). Among the most productive, we highlight here the idea of combining different levels of existence - both ideal and real in the archetype as the co-existence. Hence the relationship between the archetype as co-existence and the Great Time, when the archetype as an ideal co-existence exists in the eternal Aeon, the eternal Truth.

In this context, Heidegger's co-existence is a gathering of time together. In this it is comparable to music, which also gathers time together. This means that music is co-existence, both at the micro- and macro-levels. Confronting the objectively fluid world time that tells us nothing and that we do not feel is the only way to feel the integrity of time at the Dasein level.

Having a variable potential, the archetype as a co-existence is, according to J.-L. Nancy, the multiple singularity of existing being, when co-existence with other archetypes creates a communicative experience. In music, such an 
experience is most clearly traced in the triad of composer-performer-listener, when the abstract, potential text of the composer's work, as a certain archetype-co-existence, at different levels (from one sound, tone, timbre to different models of composer's work, genre, style) has many connotations. The latter, in turn, contain a semantic archetypal basis for "reading" this text by the performer and the listener, creating frame semantic contexts.

In M. Bakhtin's research, the concept of "coexistence" also appears to be one of the main ones. But for Bakhtin, "coexistence" is, first of all, dialogue: dialogue of cultures, dialogue of the author with the reader, dialogue with the super-addressee (Cosmos, God, Absolute, Universal Mind), dialogue of the author with himself, and others. Bakhtin's perception of human beingcoexistence is based on its fundamental ontology as ethics: to describe beingcoexistence as "the act knows it" means to show it as being with others, it means co-existence, dialogically. And then the active involvement of the individual in being-coexistence is a matter of its moral attitude to another.

In addition, the co-existence of M. Bakhtin is an "aesthetic co-existence", which became the fundamental position of the author in the work "The problem of the author and the hero in Russian literature". For a Russian researcher, the relationship between the author and the hero as participants in "aesthetic co-existence" is fundamentally important. In the context of our study, co-existence according to M. Heidegger, J.-L. Nancy and M. Bakhtin, as "being-with-many", focuses on the value nature of any aesthetic coexistence. This once again emphasizes the important role of archetypes, the problem of their choice as an act (according to Bakhtin), its (act) active involvement in being-coexistence, structured "through me and others", and, consequently, "the task of being responsible" (M. Bakhtin).

Bakhtin's conception of ontology as ethics is in many aspects consonant with H. Gadamer's hermeneutic conception. The latter understands coexistence in terms of tradition. In this question, Gadamer proceeds from a metaphysical understanding of being, namely, he distinguishes between the modes of being: invariably eternal and divine; what is constantly in motion is nature; ethos, which connects itself with moral laws - man. Thus, according to Gadamer, the tradition of metaphysics is above all, and its main themes (metaphysics of nature, metaphysics of morals that existed in Kant's time) are a specific combination of knowledge of God and moral philosophy.

$\mathrm{H}$. Gadamer sees the purpose of interpreting the text as an archetype, as co-existence, not in "reproduction" but in "creation" of meaning. This means that each author and his interpreters "bring to the surface" or "construct" an infinite number of archetypal codes that have received their "form" in a particular cultural, historical and personal context. Both M. Bakhtin, H. Gadamer, and M. Heidegger understood how powerless our scientific consciousness is in its judgments of contemporary art in terms of co-being and co-existence, as the contrast between new forms and old ones is clearly 
sharpened. And that is why today there is a "revolution" in the worldview, perception of the world, feeling of the world and relation of the man to the world. The archetype as co-existence is considered by us as a multidimensional object, which we see only as its individual projections, only the tip of this iceberg remains visible. That is why the latest artistic trends cannot be denied, because they, as a certain co-existence, represent the plurality of descriptions, images, samples of archetypes of world culture, just as it is impossible to deny everything that has become a cultural experience in the form of traditions. For great thinkers, there is no opposition between the "past" and the "present". Their imaginary opposition is "removed" due to the phenomenon of co-existence.

Thus, co-existence is our presence or co-presence in Dasein, and "co-existence of tradition" or "co-existence of archetype" is the presence (co-presence) of history in the present, which H. Gadamer calls "experience of art" and, thanks to which the "experience of history" is not interrupted, its (history) continuum. Thus, in order to understand certain archetypes as co-existence, they must be analyzed, but exploring them, you must already have an understanding of them, what H. Gadamer calls "preconception" (Vorverständnis). Thus, H. Gadamer's hermeneutics "is translated from the methodological plan to the ontological" (V. Malakhov), affirming the triumph, the feast of metaphysics, the triumph of being, and more precisely co-being, including archetypes.

In the process of communication, archetypes in a musical composition represent the world of a composer who tries to reach out, to touch the source, the prototype of this composition, constructing meanings. Therefore, we are talking about the cosmogony and, even divinity, of the composer's work, aimed at forming the integrity of perception of the world. The composer constantly "decodes" the meanings of the prototypes. Therefore, we emphasize that archetypes are multidimensional and represent a plurality of descriptions, images, faces of world culture.

\section{ЛITЕРАТУРА}

1. Арановский М. Г. Музыка и мышление. Музыка как форма интеллектуальной деятельности. Москва: Книжный дом «ЛИБРОКОМ», 2009. С.10-43.

2. Бахтин М.М. К философии поступка. Киев : «Next», 1994. 383 с.

3. Бодрийяр Ж. Система верей. Москва : «РУДОМИНО», 1999. 224 с.

4. Гадамер Г.-Г. Актуальность прекрасного. Москва : Искусство, $1991.367 \mathrm{c}$.

5. Делёз Ж. Логика смысла. Москва : Академический Проект, $2011.472 \mathrm{c}$. 
6. Дьяконов Г.В. Этика поступка и концепция «Другого» М.М. Бахтина - исток и предпосылка психологической онтологии диалога. URL : http://www.hpsy.ru.

7. Зубавіна І.Б. Кінематограф незалежної України: тенденції, фільми, постаті. Київ : ФЕНІКС, 2007. 296 с.

8. Латковська Н. Інтертекстуальність як фактор організації художнього простору у фортепіанному циклі «Мардонги» С. Луньова. Київ : Київське музикознавство. Збірка статей. Вип. 39, 2011. С. 14-23.

9. Магун А. Отрицательная революция: к деконструкции политического субъекта. Санкт-Петербург : Изд-во Европейского ун-та в Санкт-Петербурге, 2008. 416 с.

10. Малахов В.С. Философская герменевтика Г.Г. Гадамера. Гадамер Г.Г. Актуальность прекрасного. Москва: Искусство, $1991.367 \mathrm{c}$.

11.Нанси Ж.-Л. Бытие единичное множественное. Минск : Логвинов, 2004. $272 \mathrm{c}$.

12. Суханцева В. Лекции по истории метафизики URL : http://gzvon.pyramid.volia.ua/biblioteka/kafedra_filosofii/libph/sound/.

13. Успенский Б.А. Семиотика истории. Семиотика культуры. Москва : Издательство «Гнозис», 1994. Т. 1. 432 с.

14. Фуко М. Theatrum philosophicum. Делёз Ж. Логика смысла. Москва : Академический Проект, 2011. С. 438-470.

15. Хайдеггер М. Бытие и время. Харьков : «Фолио», 2003. 503, [9] с.

16. Хайдеггер М. Время и бытие : Статьи и выступления. Санкт-Петербург : Наука, 2007. 621 с.

17. Хайдеггер М. Разговор на проселочной дороге. Москва : Высшая школа, 1991. 192 с.

\section{Information about the author:} Severynova M. Yu.,

Doctor of Art History, Associate Professor, Professor at the Department of Theory and History of Culture Ukrainian National Tchaikovsky Academy of Music 1-3/11, Architect Gorodetsky str., Kyiv, Ukraine 